\title{
A DECADE OF PLANT SPECIES CHANGES ON A MIRE IN THE ITALIAN ALPS: VEGETATION-CONTROLLED OR CLIMATE-DRIVEN MECHANISMS?
}

\author{
LUCA BRAGAZZA \\ Department of Natural and Cultural Resources, University of Ferrara, Corso Porta Mare 2, \\ I-44100 Ferrara (Italy) \\ E-mailbrc@unife.it
}

\begin{abstract}
Variation of plant species cover on a Sphagnum-dominated mire in the south-eastern Alps of Italy was assessed over a 10-year period in relation to depth to the water table, peat accumulation rate, and climate. Population dynamics of vascular species appeared to be primarily affected by the autogenic process of peat accumulation, which determined the lowering of water-table position at microhabitat scale. Increase of depth to the water table through peat accumulation resulted in increased cover of ericaceous shrubs at previously moister microhabitats. Conversely, graminoid species such as Eriophorum vaginatum, Trichophorum caespitosum, and Scheuchzeria palustris, being negatively affected by autogenic peat growth, were forced to shift their niche towards the wetter end of the water-table gradient. Carex limosa and Carex rostrata decreased their cover along the whole gradient in depth to the water table, likely due to multiple processes related to peat accumulation, competition with bryophytes, and a negative feedback due to increased litter deposition. Bryophytes, in particular Sphagnum mosses, appeared more sensitive to climatic conditions, with higher precipitation favouring faster-growing species. Accordingly, Sphagnum fallax and Sphagnum magellanicum increased their cover much more than Sphagnum capillifolium, whereas Polytrichum strictum showed the strongest decrease at sites where $S$. magellanicum cover increased most.
\end{abstract}

\section{Introduction}

Sphagnum-dominated mires are permanently wet ecosystems characterised by a large accumulation of organic matter. Mire formation is common in cold-temperate climates where precipitation can exceed evapotranspiration, leading to a water surplus. Most mires occur in the Northern Hemisphere, particularly in Fennoscandia, western Siberia, Canada, and Alaska, where estimates of boreal and sub-arctic mires range from 2.5 to 4 million $\mathrm{km}^{2}$ (Mitsch and Gosselink, 2000).

Anaerobic conditions, coupled with acidic $\mathrm{pH}$ and low nutrient content of substrates, hamper the decomposing activity of microbes, thus favouring peat accumulation. Sphagnum plants, particularly ombrotrophic species, rely heavily on atmospheric inputs for their nutrient requirement and are well adapted to survive under low nutrient availability (van Breeman, 1995). Their growth habit is characterised by indefinite apical elongation of stems that emerge as a rise of the mire surface by gradual peat accumulation, which in turn enhances both the insulation of the mire from local groundwater and the creation of ombrotrophic (i.e., fed by rainfall) conditions. Hence, ombrotrophic conditions are the result of, and the reason for, 
the dominance of Sphagnum plants that form the bulk of organic biomass in ombrotrophic mires. The few vascular species found in Sphagnum-dominated mires must be adapted to low nutrient availability, anoxic conditions in the peat substrate, acidic conditions, and low peat temperature. In addition, vascular bog species must be able to keep pace with the vertical growth of Sphagnum mosses (Malmer et al., 1994; Breeman van, 1995).

Sphagnum-dominated mires are characterised by notable topographic heterogeneity over a few centimetres, with an alternating pattern of hummocks (i.e., relatively higher mounds), carpets (i.e., relatively flat zones), and hollows (i.e., relatively lower depressions). Depth to the water table, oxygenation, redox potential, $\mathrm{pH}$, and nutrient availability are the most prominent environmental factors varying along the hummock-hollow gradient (Bridgham et al., 1996). Changes in environmental factors are reflected in a different bryophyte and vascular plant species assemblage along the hummock-hollow gradient (Andrus, 1986).

Sphagnum-dominated mires are the result of a dynamic process culminating in a compositionally stable community (Klinger, 1996). Allogenic factors, such as climatic conditions, are supposed to play a major role in controlling peat accumulation and plant succession during the early stages of mire formation, whereas autogenic factors, such as peat accumulation rates and biotic interactions, gain importance during later stages (Kratz and DeWitt, 1986). Ombrotrophic mires appear rather stable ecosystems, being characterised by very small or even no changes in floristic composition over periods of several decades (Backéus, 1972; Gunnarsson et al., 2000; Gunnarsson et al., 2002). In addition, long-term stability of microtopographic patterns in ombrotrophic mires has been documented for periods of several centuries to millennia (Barber, 1981; Svensson, 1988; Rydin and Barber, 2001). Conversely, significant changes in plant species dominance can occur at the micro-community level over relatively shorter time scales as a result of the competitive balance among plant species changing with environmental conditions, such as climatic and/or precipitation chemistry (Hogg et al., 1995; Nordbakken, 2001; Gunnarsson et al., 2002).

The understanding of potential direct and indirect effects of climatic variability on mire plant species can be helpful to predict the future of mires (Moore et al., 1998; Moore, 2002). Indeed, peat-forming ecosystems are not only important carbon sinks (Gorham, 1991; Wieder, 2001), but they also harbour relic plant species, particularly on the southern part of mire distribution in Europe, which increases local biodiversity. An effective management and preservation of these ecosystems can be obtained by a better knowledge of the response of mire plant species to autogenic and allogenic factors over time.

The present paper aims to advance understanding of plant species dynamics by studying 10-years changes in plant cover along a gradient of water-table depth at a Sphagnum-dominated mire in the south-eastern Alps of Italy. The main objective of the study was to unravel the role of autogenic and climate-driven succession mechanisms. 


\section{Materials and Methods}

\subsection{STUDY AREA}

The study was carried out at Stallner Loch, a Sphagnum-dominated mire located on the Sarntaler Alpen (Monti Sarentini) at $1720 \mathrm{~m}$ a.s.l., province of Bozen (Bolzano), in the south-eastern Alps of Italy $\left(46^{\circ} 30^{\prime} \mathrm{N}, 11^{\circ} 19^{\prime} \mathrm{E}\right)$. The mire has an elliptical shape, $c a .180 \mathrm{~m}$ long by $c a .70 \mathrm{~m}$ wide (Bragazza and Gerdol, 1999). The maximum peat depth is $c a .8 \mathrm{~m}$ and the total area with a peat thickness $>15 \mathrm{~cm}$ is $c a .1 .2 \mathrm{ha}$ (Bragazza and Gerdol, 1999).

On the whole, based on previous floristic, hydrological and geochemical studies (see Gerdol et al., 1994; Bragazza and Gerdol, 1999), Stallner Loch can be described as an extremely poor fen for being influenced by mineral soil water just along the margins. The main vegetation types at Stallner Loch can be briefly described as follows:

(1) High hummocks dominated by Sphagnum capillifolium (Ehrh.) Hedw., mainly developed in the mire margin and the upslope, dry part of the mire. Typical species are S. capillifolium, Polytrichum strictum Menz. ex Brid., Calluna vulgaris L. (Hull), Vaccinium vitis- idaea L., and Eriophorum vaginatum L.

(2) Low hummocks and carpets dominated by Sphagnum magellanicum Brid., concentrated in the central part of the mire. The field layer is characterised by Carex pauciflora Lightf., E. vaginatum, Vaccinium microcarpum (Turcz.) Hooker f., C. vulgaris, and V. vitis-idaea.

(3) Hollows dominated by Sphagnum subsecundum Nees and Drepanocladus fluitans (Hedw.) Warnst., confined to the downslope, wet portion of the mire. Typical vascular species are Carex rostrata Stokes, Carex limosa L., and Scheuchzeria palustris L.

The surrounding area is covered by upland forests of Norway spruce (Picea abies (L.) Karst). The mineral substrate consists of ignimbrite of Early Permian Age. Nomenclature for vascular plants follows Pignatti (1982), nomenclature for Sphagnum species follows Daniels and Eddy (1990) and Frahm and Frey (1987) for the other bryophytes.

\subsection{CLIMATIC CONDITIONS}

Climatic conditions at Stallner Loch were estimated by adjusting data collected at a nearby meteorological station (Sarnthein, $960 \mathrm{~m}$ a.s.l., distance from the mire ca. $4 \mathrm{~km})$ for effects of elevation. Gradients in temperature $\left(-0.62{ }^{\circ} \mathrm{C} \times 100 \mathrm{~m}\right.$ elevation) and precipitation $(+12.3 \mathrm{~mm} \times 100 \mathrm{~m}$ elevation) were calculated using climatic data from a number of meteorological stations in Bozen province (data not 
shown). The mean climatic conditions at Stallner Loch during the period 19922002 were characterised by a mean annual temperature of $c a .+1.8^{\circ} \mathrm{C}$ and a total annual amount of precipitation of $c a .1010 \mathrm{~mm}$.

Daily potential evapotranspiration (ETP) was calculated using Hamon's formula (Haith and Shoemaker, 1987):

$$
\operatorname{ETP}\left(\mathrm{mm} \mathrm{day}^{-1}\right)=\left(2.1 \times H_{\mathrm{n}}^{2} \times e_{\mathrm{s}}\right) /\left(T_{\mathrm{n}}+273.2\right)
$$

where $H_{\mathrm{n}}=$ average number of daylight hours per day during the month in which day $\mathrm{n}$ falls, $T_{\mathrm{n}}=$ mean temperature of day $\mathrm{n}\left({ }^{\circ} \mathrm{C}\right)$, and $e_{\mathrm{s}}=$ saturated vapour pressure at temperature $T_{\mathrm{n}}(\mathrm{kPa})$.

Effective precipitation during the growing season was defined as the difference between precipitation and ETP during the period characterised by mean daily temperatures $>5^{\circ} \mathrm{C}$.

\subsection{VEGETATION SAMPLING, WATER-TABLE MONITORING, AND PEAT ACCUMULATION}

At the beginning of the 1991 growing season, 50 sampling plots were positioned so to encompass all the major microhabitats. Plots were all located in the mire sector with a peat thickness $>15 \mathrm{~cm}$. At each sampling plot, a 1-m long perforated polyvynylchloride tube (inner diameter $14 \mathrm{~mm}$, wall thickness $2 \mathrm{~mm}$ ) was inserted into the peat with the top placed level with the mire surface. Depth to the water table in the 50 PVC tubes was measured at intervals of $10 \pm 2$ days from May 21 to October 7, 1991. The plots were then grouped into seven classes of median depth to the water table. Positive values of depth to the water table indicate a water-table position above the mire surface, whereas negative values indicate positions below the mire surface.

At the end of July 1992, the presence/absence of all plant species around each sampling plot was determined in a $25 \times 25 \mathrm{~cm}$ quadrat sub-divided into $25,5 \times$ $5 \mathrm{~cm}$ sub-quadrats. The distribution of plant species across the gradient in depth to the water table, i.e., the niche breadth, was determined based on the water-table measurements carried out in 1991. As the top of each pipe was positioned level with the peat surface in 1992, thickness of the peat accumulated over the top in 2002 has been used to estimate surface peat growth. A sub-set of three to six pipes were available for each class of water-table depth to estimate mean peat accumulation rates over 10 years.

\subsection{TEMPORAL VARIATION OF PLANT SPECIES FREQUENCY AND STATISTICAL ANALYSES}

The frequencies of those plant species occurring in at least 5\% of the plots in 1992 were re-determined in the same plots at the beginning of August 2002 as above. 
Change in the frequency of plant species was calculated for each class of median depth to the water table based on frequency difference between 1992 and 2002. All statistical analyses were performed using Statistica for Windows v. 6.0 (StatSoft Italia srl, 2001).

\section{Results}

\subsection{CLIMATIC CONDITIONS}

Mean annual temperature was higher than the log-term (1977-2002) average during the period 1992-1997, and lower than long-term average during the period 19982001 (Figure 1). Annual precipitation and effective precipitation during the growing season showed a variable trend during the period 1992-1997, but both were higher than the long-term average in 1998-2001, indicating relatively cooler conditions during the four years preceding the 2002 sampling (Figure 1).

\subsection{SPECIES NICHE BREADTH AND PEAT ACCUMULATION}

Among the vascular plants, ericaceous shrubs such as V. uliginosum and V. myrtillus were significantly concentrated on the driest end of the water-table gradient, whereas sedges such as $C$. limosa, S. palustris, and C. rostrata were mostly found

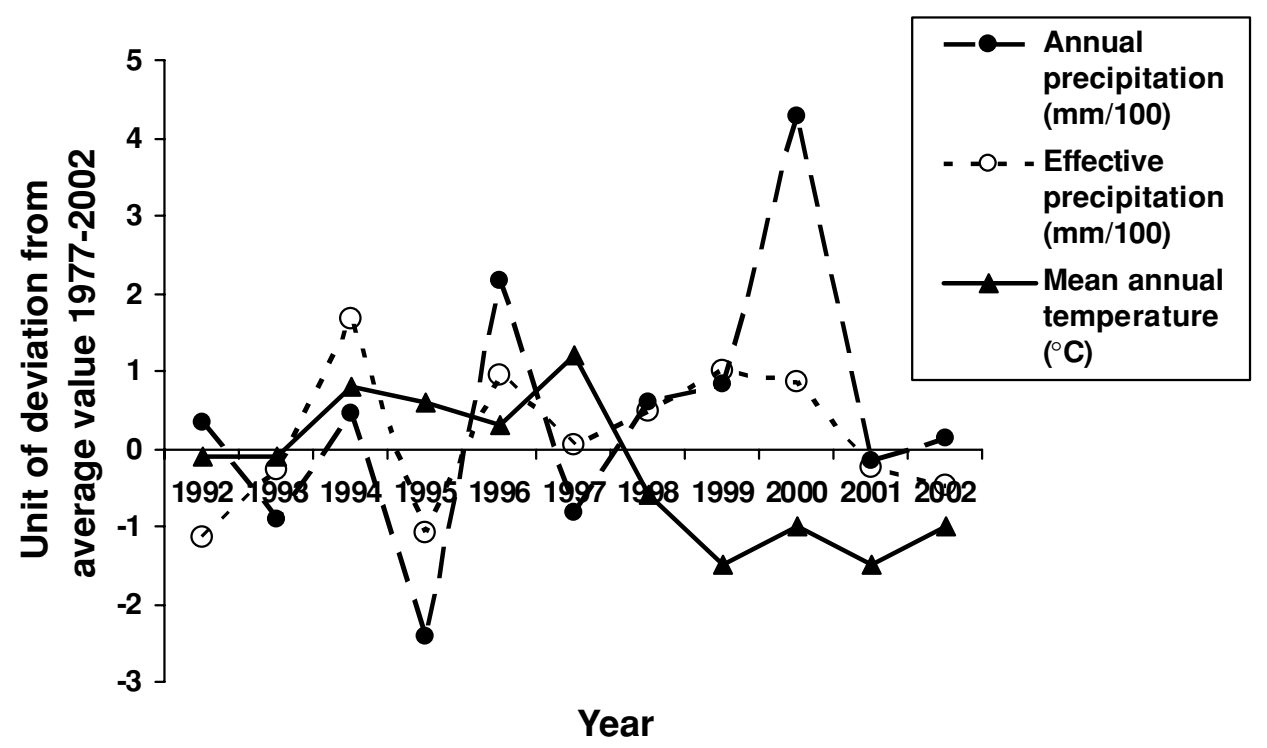

Figure 1. Deviation of mean annual temperature, annual precipitation, and effective precipitation during the period 1992-2002 from the 1977-2002 average values at Stallner Loch $\left(46^{\circ} 30^{\prime} \mathrm{N} ; 1^{\circ}\right.$ $\left.19^{\prime} \mathrm{E}\right)$. 


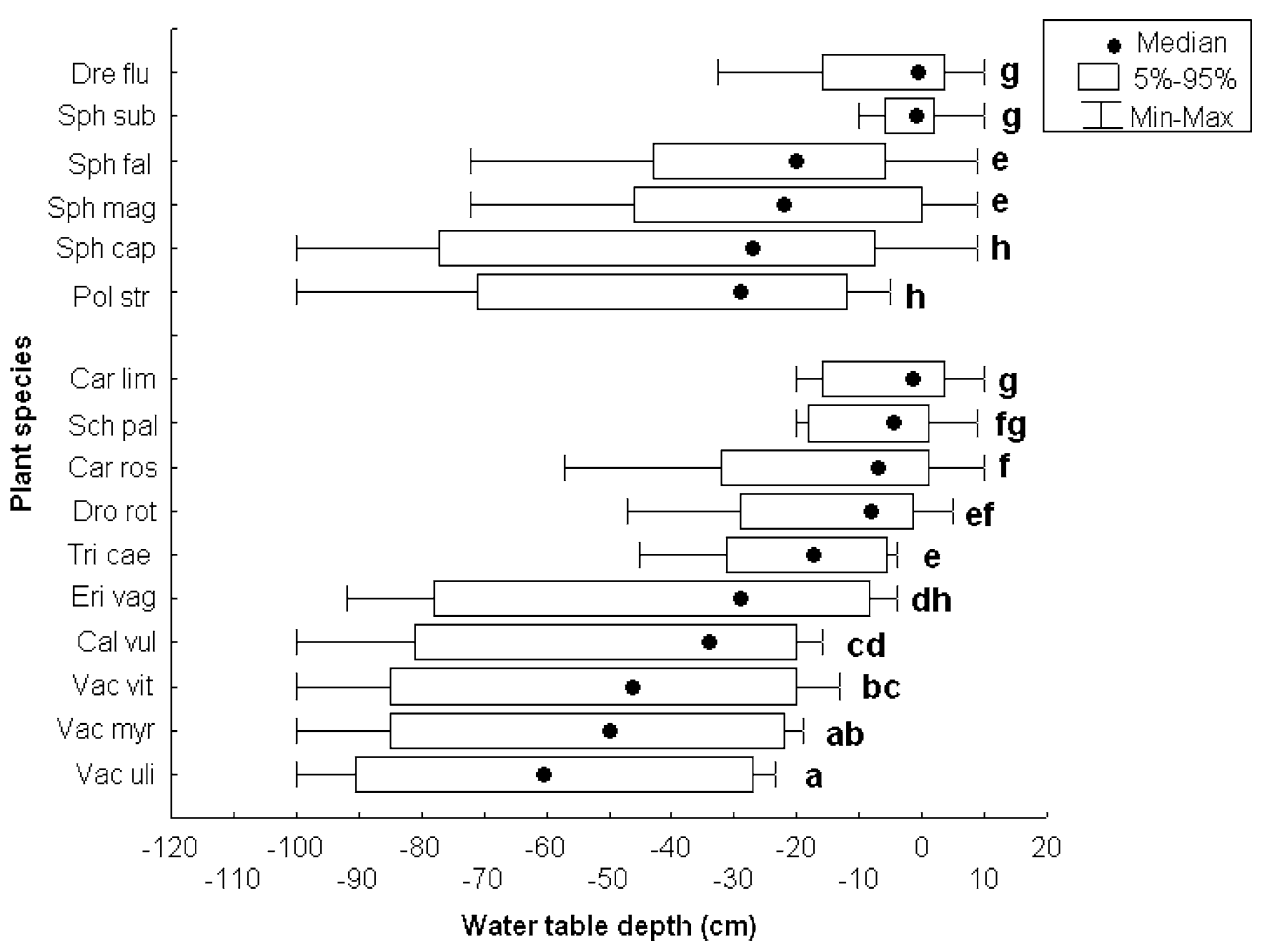

Figure 2. Distribution of plant species along the gradient in depth to the water table based on watertable measurements in 50 sampling plots in 1991. Median, minimum, and maximum refer to plots where each plant species was present. (Plant names are composed of the first three letters of the genus and the species name, respectively, as from Table II). Different superscripts indicate significant differences at $P<0.05$ based on ANOVA and Fisher post-hoc test.

on the wettest end of the gradient (Figure 2). Among the bryophytes, S. subsecun$d u m$ and $D$. fluitans were found on the wettest portion of the water table gradient, whereas $S$. capillifolium and $P$. strictum were significantly more abundant on drier microhabitats (Figure 2).

Peat accumulation (Figure 3) was significantly lower in the driest microhabitats (median depth to the water table $<-30 \mathrm{~cm}$ ). The wettest microhabitats (median depth to the water table $>0 \mathrm{~cm}$ ) showed intermediate rates of peat accumulation. Microhabitats located in the central portion of the water-table gradient showed the greatest mean peat accumulation, significantly different $(P<0.05)$ from the driest and the wettest microhabitats (Figure 3).

\subsection{CHANGES IN PLANT SPECIES FREQUENCY OVER 10 YEARS ALONG THE WATER-TABLE GRADIENT}

The frequency of all species changed significantly between 1992 and 2002 (Table I), but no new plant species were detected in 2002. Among the vascular plant 
TABLE I

Significance of plant species changes at Stallner Loch after 10 years. Significance probability $(P)$ refers to $\chi^{2}$ test between the frequency determined at each sampling plot in 1992 and in 2002 for the selected plant species

\begin{tabular}{lrl}
\hline & \multicolumn{1}{l}{$\chi^{2}$} & $P$ \\
\hline Vascular species & & \\
Vaccinium uliginosum & 16.0 & $<0.003$ \\
Vaccinium myrtillus & 76.2 & $<0.000$ \\
Vaccinium vitis-idaea & 39.4 & $<0.000$ \\
Calluna vulgaris & 54.1 & $<0.000$ \\
Eriophorum vaginatum & 129.1 & $<0.000$ \\
Trichophorum caespitosum & 23.5 & $<0.009$ \\
Carex rostrata & 90.9 & $<0.000$ \\
Drosera rotundifolia & 11.2 & $<0.005$ \\
Scheuchzeria palustris & 26.5 & $<0.000$ \\
Carex limosa & 59.1 & $<0.000$ \\
Bryophytes & & \\
Polytrichum strictum & 107.1 & $<0.000$ \\
Sphagnum capillifolium & 127.9 & $<0.000$ \\
Sphagnum magellanicum & 82.5 & $<0.000$ \\
Sphagnum fallax & 23.5 & $<0.009$ \\
Sphagnum subsecundum & 39.9 & $<0.000$ \\
Drepanocladus fluitans & 10.3 & $<0.007$ \\
\hline
\end{tabular}

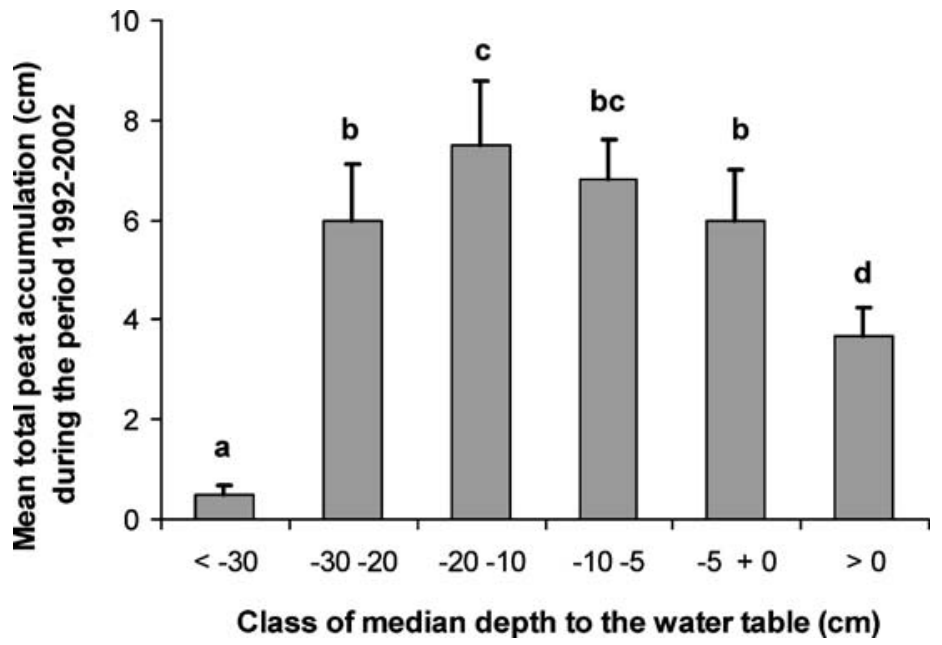

Figure 3. Mean total peat accumulation $( \pm$ s.d.) along the water-table gradient during the period 1992-2002. Different superscripts indicate significant differences at $P<0.05$ based on ANOVA and Fisher post-hoc test. 
species, ericaceous shrubs showed either increased or constant frequency, but did not colonise any new habitat (Table II). In fact, none of the ericaceous species was found in a different class of depth to the water table in 2002 compared to 1992. The frequencies of E. vaginatum, S. palustris, and T. caespitosum decreased on the dry end of the water-table gradient, but increased in wetter habitats. Trichophorum caespitosum even colonized new habitats at median depth to the water table between 0 and $-5 \mathrm{~cm}$ (Table II). Carex rostrata and $C$. limosa were the only vascular plant species showing a considerable decrease in their frequency across the whole gradient, whereas $D$. rotundifolia was the only species colonizing new habitats in the wet part of the water-table gradient (Table II).

Among the bryophytes, frequencies of S. fallax, D. fluitans, S. magellanicum, and $S$. subsecundum increased almost in all the classes of depth to the water table, with S. fallax colonizing new habitats (Table II). In contrast, frequencies of $S$. capillifolium and P. strictum declined in dry habitats.

There was a negative relationship between median position along the water-table gradient and frequency variation for vascular plant species, indicating that species from relatively drier microhabitats showed an increment of their frequency compared to plant species from wetter microhabitats (Figure 4). Differently, bryophytes from wetter microhabitats showed a significant increase of their frequency, much more than bryophytes of drier microhabitats (Figure 4).

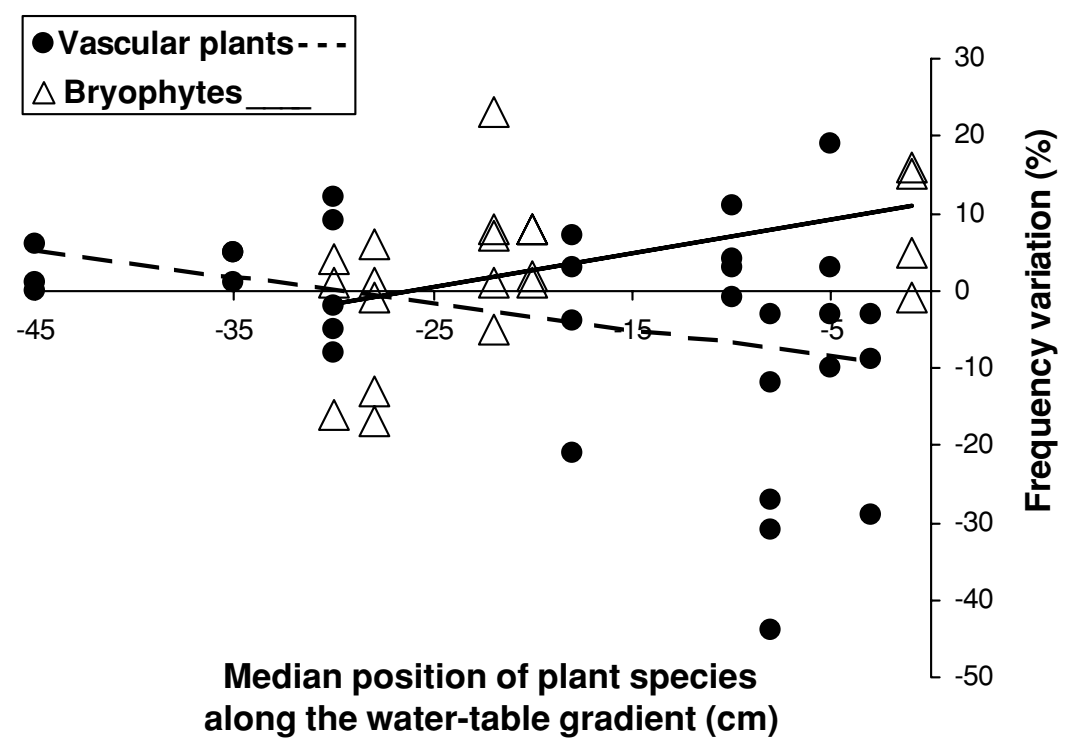

Figure 4. Relationship between median position $(\mathrm{cm})$ of vascular plant and bryophyte species along the gradient of water-table depth with the corresponding frequency changes (\%) from 1992 to 2002. Linear regression is indicated by a segmented line for vascular plant species $(Y=-0.34 X-10.3$; $\left.R^{2}=0.13 ; P=0.054\right)$, and by a continuous line for bryophytes $\left(Y=0.44 X+11.3 ; R^{2}=0.20\right.$; $P=0.039)$. 


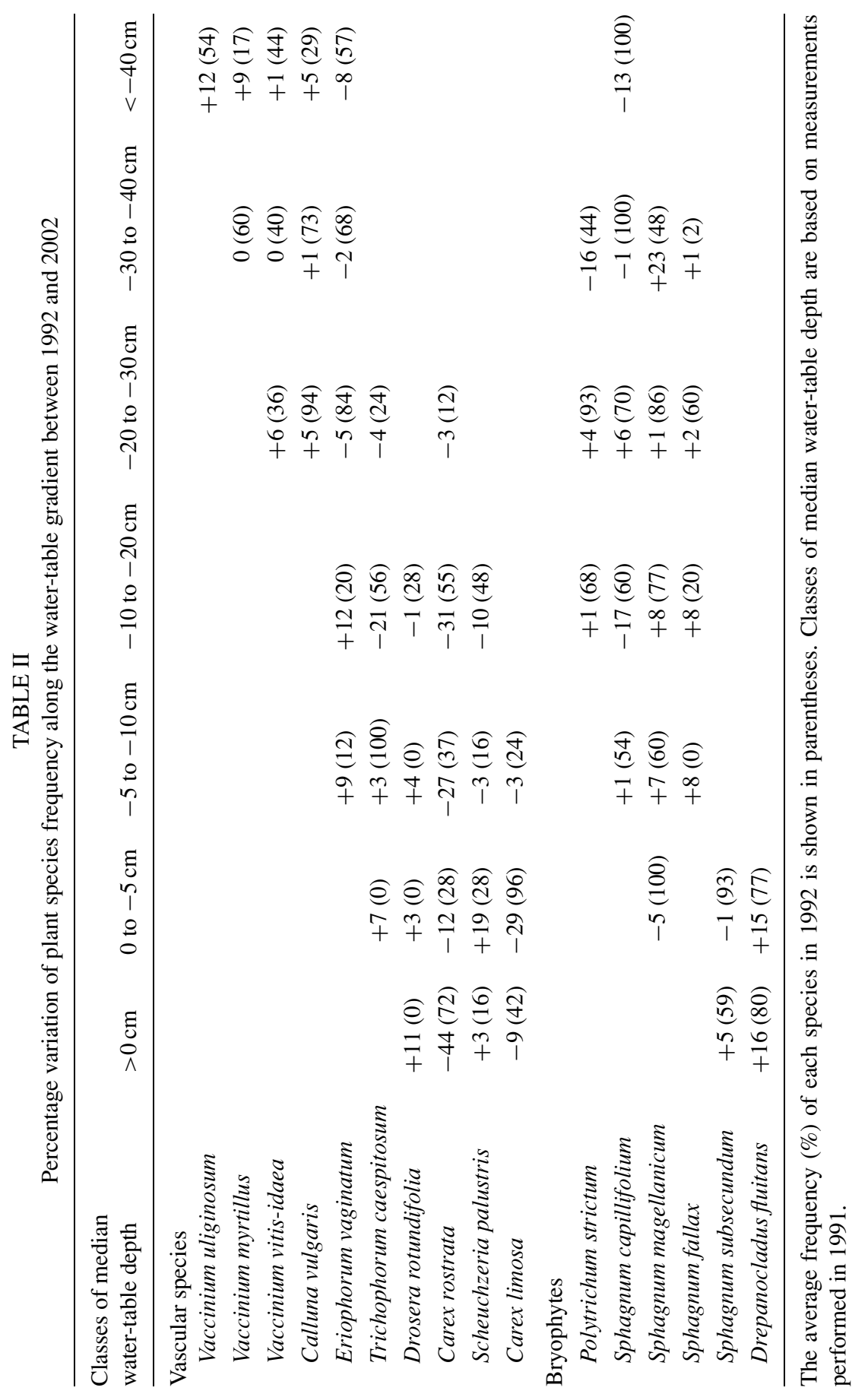




\section{Discussion}

\subsection{VASCULAR PLANT DYNAMICS}

Vaccinium myrtillus and V. uliginosum represent typical forest species and, consistently, their distribution at Stallner Loch was confined to the mire margin with shallow peat and relatively deep water table (Bragazza, 1999; Bragazza and Gerdol, 1999). The role of substrate aeration in affecting the distributional pattern of V. myrtillus and $V$. uliginosum was consistent with the narrow niche of these ericaceous species at the driest end of the water- table gradient, where relatively drier conditions hamper peat accumulation. Notwithstanding the cooler climatic conditions in the four years preceding the 2002 sampling, V. myrtillus and $V$. uliginosum generally increased their frequency (Table II). This trend is consistent with hydrological conditions of the mire margin at Stallner Loch, which was characterised by wider water-table fluctuations that favoured peat aeration (Bragazza, 1996; Bragazza and Gerdol, 1999).

The other ericaceous plant species, i.e., $C$. vulgaris and $V$. vitis-idaea, increased their frequency in the wetter portion of their niche, probably favoured by peat accumulation. Increased cover of $C$. vulgaris has been observed in European mires as a consequence of lowered water table (e.g., Malmer and Wallen, 1993; Frankl and Schmeidl, 2000; Nordbakken, 2001). By increasing depth to the water table at the microhabitat scale, autogenic peat accumulation may have enhanced $C$. vulgaris and $V$. vitis-idaea frequencies despite relatively humid climatic conditions in recent years (Figure 1). It is worthy to observe that $C$. vulgaris and V. vitis-idaea were not able to colonise new habitats, in particular the median water-table class -10 to $-20 \mathrm{~cm}$ (Table II), indicating that peat accumulation during 10 years was not yet sufficient to create suitable aerated conditions for these ericaceous plants to establish, in accordance with their water-table niche (Figure 2).

The role of autogenic peat accumulation in affecting niche shifts across the water-table gradient could also explain the frequency variation observed for $E$. vaginatum, T. caespitosum, and S. palustris. All of these species showed decreased frequencies in the drier end of the gradient, but increased frequencies in wetter habitats (Table II). This trend seems to corroborate the role of autogenic peat growth in controlling the moisture of the peat surface, causing the shift of plants typical of wet habitats towards the wetter end of the water-table gradient. For example, a generalized decrease in the frequency of $S$. palustris has been observed at many European mires, due to its sensitivity to dry conditions (Tallins and Birks, 1965; Gunnarsson et al., 2002). The only species capable to colonize new habitats was T. caespitosum, which was found, in 2002, in the water-table class 0 to $-5 \mathrm{~cm}$ (Table II) where mean peat accumulation was $c a .6 \mathrm{~cm}$ (Figure 2). In this case, peat accumulation was sufficient to create suitable conditions for T. caespitosum, but not for E. vaginatum, another graminoid morphologically similar to T. cae- 
spitosum. The different ability to colonize new habitats between T. caespitosum and $E$. vaginatum reflects a different ability to withstand anaerobic conditions, in accordance with their significantly different position along the water-table gradient (Figure 2).

Carex rostrata and $C$. limosa showed decreased frequencies across the whole water-table gradient (Table II). Sedges are particularly sensitive to depth to the water table, favouring relatively wet microhabitats (Bayley et al., 1985; Thormann et al., 1998). Peat accumulation can be claimed as responsible for the decline of Carex species, particularly on the relatively drier hand of the water-tale gradient (Table II). Accordingly, a rapid decline in sedge frequency has been reported after peatland drainage (Laine et al., 1995) or water-table manipulation in mesocosm experiments (Weltzin et al., 2000, 2003). Anyway, the strong decrease of $C$. rostrata and $C$. limosa frequencies in the wettest end of the watertable gradient can not be explained by peat accumulation alone. Two other possible explanations can be taken into account. The first explanation is related to competition with bryophytes (Bernard et al., 1988), in particular S. subsecundum and $D$. fluitans, which increased their frequency (see also the chapter below) at median water-table depth $>-5 \mathrm{~cm}$, where Carex species showed the greatest frequency decrease (Table II). A second possible explanation stems from the significant correlation between Carex shoot density in 1992 and subsequent frequency decrease (Pearson's correlation $=-0.80 ; P<0.05$ ), indicating a densityrelated factor. In this case, experimental manipulations have shown that Carex dynamic is negatively affected by litter deposition ("thatch" effect) after some years of increased biomass production, the latter enhanced by high precipitation amounts (Thormann and Bayley, 1997a, b; Weltzin et al., 2000, 2003). Indeed, when accumulation of litter reaches critical levels for reducing light penetration and/or peat temperature, sedge biomass decreases. Unfortunately, the present data cannot unravel the ultimate role played by biotic competition and litter deposition, although we cannot exclude that both the effects are connected by a positive feedback, i.e., increased litter deposition after a period of enhanced biomass growth can reduce Carex shoot density, which, in its turn, can favour bryophyte growth.

Drosera rotundifolia was the only vascular plant colonizing new habitats in the wet part of the water-table gradient. Drosera species are short-lived perennials confined to moist habitats due to their shallow rooting system (Crowder et al., 1990). Persistence of D. rotundifolia in mires is generally low (Nordbakken, 2000) due to wide fluctuations in population density (De Ridder and Dhondt, 1992). The increase in $D$. rotundifolia frequency was in accordance with the relatively more humid climatic conditions in recent years (Figure 1), since summer drought is detrimental for adult survival (De Ridder and Dhondt, 1992).

On the whole, the role of autogenic peat accumulation in affecting vascular plant species dynamic is supported by the tendency of species from the drier end of the water-table gradient to increase their frequency, differently from species 
from the wetter end of the gradient where a general decrease of the frequency was observed.

\subsection{BRYOPHYTE DYNAMICS}

Biomass production by peatland mosses fluctuates widely from year to year, due to variations in precipitation and, to a lesser extent, air temperature (Backéus, 1988; Thormann and Bayley, 1997a, 1997b; Weltzin et al., 2000; Sonesson et al., 2002). Depth to the water table, which is directly affected by fluctuations in precipitation, is a major environmental factor controlling bryophytes dynamics through its influence on tissue water content of poikilohidric mosses (Rydin, 1993; Weltzin et al., 2001). Niche overlap among Sphagnum species along the water-table gradient has been shown to be rather wide (e.g., Nordbakken, 1996; Bragazza, 1997). Indeed, Sphagnum plants have been defined as "competitive equivalents", since they do not show any mutual competitive exclusion under "normal" climatic conditions (Rydin, 1993). Remarkable changes in Sphagnum species cover can take place in relation to short-term climate fluctuations, which can temporarily alter the competitive equilibria among co-existing species (Moore, 1989; Silvola, 1992).

At the dry end of the water-table gradient, decrease of $S$. capillifolium coincided with increase of ericaceous shrubs. This trend is consistent with the negative effect that a dense vascular plant layer exerts on bryophytes (see Bergamini et al., 2001), primarily through light absorption and litter deposition (Malmer et al., 1994; Hogg et al., 1995). In contrast, S. magellanicum and S. fallax increased in frequency across the entire water-table gradient (Table II). Relatively wetter conditions in recent years may explain this shift of Sphagnum species that are competitive dominants in wetter microhabitats. Indeed, Sphagnum species in the Cuspidata Section possess a competitive advantage in wet conditions (Hayward and Clymo, 1983; Brock and Bregman, 1989; Rydin, 1993; Gerdol, 1995), with $S$. fallax growing faster than $S$. capillifolium under greater water availability (Titus and Wagner, 1984; Grosvernier et al., 1997).

The decrease in frequency of $P$. strictum in dry habitats may have been driven by increased cover of $S$. magellanicum. Once established, $P$. strictum is able to survive for long periods through vegetative production of new shoots, keeping pace with Sphagnum growth (Li and Vitt, 1995). Under favourable conditions for Sphagnum growth, however, competitive interactions cause a decline in $P$. strictum cover ( $\mathrm{Li}$ and Vitt, 1995; Weltzin et al., 2001).

Sphagnum subsecundum and D. fluitans were confined to the inner sector, i.e., the mire expanse (Bragazza, 1999). The expanse is characterised by conditions of hydrological recharge which enhances the moisture content in the peat (Bragazza and Gerdol, 1999). Wetter climatic conditions in recent years, coupled with favourable hydrological conditions probably were the reasons why the 
frequencies of $S$. subsecundum and D. fluitans slightly increased or remained stable.

\section{Conclusion}

This study revealed that plant population density is highly dynamic at the microhabitat scale, with most plant species showing an individualistic response to environmental changes, also inside the same life-form group. On the whole, population dynamics of bryophytes appeared primarily affected by climatic conditions, in particular precipitation, which can temporarily alter competitive equilibria among plant species. Vascular plants were also affected by moisture conditions, but in this case, a major role was played by the autogenic growth of the mire surface through peat accumulation, which in turn affects the depth to the water table at the microhabitat scale.

The complex interactions between climate, peat accumulation and plant responses as shown in the present paper claim for the start of long-term field investigations of plant species dynamics, so to collect information helpful to forecast the future of peat-producing ecosystems under ongoing climatic changes.

\section{Acknowledgments}

Thanks are due to I. Targa for field assistance and to L. Belyea and R. Gerdol for helpful suggestions. The Hydrographic Office (Hydrographisches Amt) of Bozen Province, in particular Mr Claudio Mutinelli, is kindly acknowledged for providing meteorological data. A previous version of the manuscript has been improved thanks to the suggestions of J. Pastor and three anonymous reviewers.

\section{References}

Andrus, R. E.: 1986, 'Some aspects of Sphagnum ecology', Can. J. Bot 64, 416-426.

Backéus, I.: 1972, 'Bog vegetation re-mapped after sixty years', Oikos 23, 384-393.

Backéus, I.: 1988, 'Weather variables as predictors of Sphagnum growth on a bog', Holarctic Ecol. 11, 146-150.

Barber, K. E.: 1981, Peat Stratigraphy and Climatic Change: A Palaeoecological Test of the Theory of Cyclic Peat Bog Regeneration, A.A. Balkema, Rotterdam, p. 242.

Bayley, S. E., Zoltek, J. Jr, Herman, A. J., Dolan, T. J. and Tortora, L.: 1985, 'Experimental manipulation of nutrients and water in a freshwater marsh: Effects on biomass, decomposition, and nutrient accumulation', Limnol. Oceanogr 30, 500-512.

Bergamini, A., Pauli, D., Peintinger, M. and Schmid, B.: 2001, 'Relationships between productivity, number of shoots and number of species in bryophytes and vascular plants', J. Ecol. 89, 920-929.

Bernard, J. M., Solander, D. and Kvet, J.: 1988, 'Production and nutrient dynamics in Carex wetlands'. Aquat. Bot. 30, 125-147.

Bragazza, L.: 1996, 'Delimitation of the aerobic peat layer in a Sphagnum mire on the Southern Alps', Oecol. Mont. 5, 41-46. 
Bragazza, L.: 1997, 'Sphagnum niche diversification in two oligotrophic mires in the southern Alps of Italy', The Bryologist 100, 507-515.

Bragazza, L. and Gerdol, R.: 1999, 'Hydrology, groundwater chemistry and peat chemistry in relation to habitat conditions in a mire on the South-Eastern Alps of Italy', Plant Ecol. 144, 243-256.

Bragazza, L.: 1999, 'Spatial pattern of plant species in a poor mire on the Southern Alps (Italy)', Plant Biosystems 113, 83-92.

Breeman van, N.: 1995, 'How Sphagnum bogs down other plants', Trends Ecol. Evol. 10, 270-275.

Bridgham, S.D, Pastor, J., Janssens, J. A., Chapin, C. and Malterer, T. J.: 1996, 'Multiple limiting gradients in peatlands: A call for a new paradigm', Wetlands 16, 45-65.

Brock, T. C. M. and Bregman, R.: 1989, 'Periodicity in growth, productivity, nutrient content and decomposition of Sphagnum recurvum var. mucronatum in a fen woodland', Oecologia 80, 44-52.

Crowder, A. A., Pearson, M. C., Grubb, P. J. and Langlois, P. H.: 1990, 'Drosera L. Biological Flora of the British Isles', J. Ecol. 78, 233-267.

Daniels, R. E. and Eddy, A.: 1990, Handbook of European Sphagna, Balogh Scientific Books, p. 263.

De Ridder, F. and Dhondt, A. A.: 1992, 'The demography of a clonal herbaceous perennial plant, the longleaved sundew Drosera intermedia in different heathlands habitats', Ecography 15, 129-143.

Frahm, J.-P. and Frey, W.: 1987, Moosflora, UTB, Stuttgart, p. 528.

Frankl, R. and Schmeidl, H.: 2000, 'Vegetation change in a South German raised bog: ecosystem engineering by plant species, vegetation switch or ecosystem feedback mechanisms?', Flora 195, 267-276.

Gerdol, R., Tomaselli, M. and Bragazza, L.: 1994, 'A floristic- ecological classification of five mires sites in the montane-subalpine belt of South Tyrol (S Alps, Italy)', Phyton (Horn, Austria) 34, $35-56$.

Gerdol, R.: 1995, 'The growth dynamics of Sphagnum based on field measurements in a temperate bog and on laboratory cultures', J. Ecol. 83, 431-437.

Gorham, E.: 1991, 'Northern peatlands: Role in the carbon cycle and probable responses to climatic warming', Ecol. Appl. 1, 182-195.

Grosvernier, P., Matthey, Y. and Buttler, A.: 1997, 'Growth potential of three Sphagnum species in relation to water-table level and peat properties with implications for their restoration in cut-over bogs' J. Appl. Ecol. 34, 471-483.

Gunnarsson, U., Rydin, H. and Sjörs, H.: 2000, 'Diversity and pH changes after 50 years on the boreal mire Skattlösbergs Stormosse, central Sweden', J. Veg. Sci. 11, 277-286.

Gunnarsson, U., Rydin, H. and Malmer, N.: 2002, 'Dynamic or constancy in Sphagnum dominated mire ecosystems? A 40-year study', Ecography 25, 685-704.

Haith, D. A. and Shoemaker, L. L.: 1987, 'Generalized watershed loading functions for stream flow nutrients', Water Res. Bull. 23, 471-478.

Hayward, P. M. and Clymo, R. S.: 1983, 'The growth of Sphagnum: experiments on, and simulation of, some effects of light flux and water-table depth', J. Ecol. 71, 845-863.

Hogg, P., Squires, P. and Fitter, A. H.: 1995, 'Acidification, nitrogen deposition and rapid vegetational change in a small valley mire in Yorkshire', Biol. Conserv. 71, 143-153.

Klinger, F.: 1996, 'The myth of the classic hydrosere model of bog succession', Arct. Alp. Res. 28, $1-9$.

Kratz, T. K. and DeWitt, C. B.: 1986, 'Internal factors controlling peatland-like ecosystem development', Ecology 67, 100-107.

Laine, J., Vasander, H. and Laiho, R.: 1995, 'Long-term effects of water level drawdown on the vegetation of drained pine mires in southern Finland', J. Appl. Ecol. 32, 785-802.

Li, Y. and Vitt, D. H.: 1995, 'The dynamics of moss establishment: temporal responses to a moisture gradient', J. Bryol. 18, 677-687.

Malmer, N. and Wallen, B.: 1993, 'Accumulation and release of organic matter in ombrotrophic bog hummocks: processes and regional variation', Ecography 16, 193-211. 
Malmer, N., Svensson, B. M. and Wallen, B.: 1994, 'Interactions between Sphagnum mosses and field layer vascular plants in the development of peat-forming systems', Folia Geobot. Phytotax. 29, 483-496.

Mitsch, W. and Gosselink, J. G.: 2000, Wetlands, John Wiley \& Sons, Inc., New York, p. 917.

Moore, P. D.: 2002, 'The future of cool temperate bogs', Environmental Conservation 29, 3-20.

Moore, T. R., Roulet, N. T. and Waddington, J. M.: 1998, 'Uncertainty in predicting the effect of climatic change on the carbon cycling of Canadian peatlands', Clim. Change 40, 229-245.

Moore, T. R.: 1989, 'Growth and net production of Sphagnum at five fen sites, subarctic eastern Canada', Can. J. Bot. 67, 1203-1207.

Nordbakken, J.-F.: 1996, 'Plant niches along the water-table gradient on an ombrotrophic mire expanse', Ecography 19, 114-121.

Nordbakken, J.-F.: 2000, 'Fine scale persistence of boreal bog plants', J. Veg. Sci. 11, 269-276.

Nordbakken, J.-F.: 2001, 'Fine scale five year vegetation change in boreal bog vegetation', J. Veg. Sci. 12, 771-778.

Pignatti, S.: 1982, Flora d'Italia, Edagricole, Bologna.

Rydin, H.: 1993, 'Mechanisms of interactions among Sphagnum species along water-level gradients', Adv. Bryol. 5, 153-185.

Rydin, H. and Barber, K. E.: 2001, 'Long-term and fine-scale coexistence of closely related species', Folia Geobot. 36, 53-61.

Silvola, J.: 1992, 'Moisture dependence of $\mathrm{CO}_{2}$ exchange and its recovery after drying in certain boreal forest and peat mosses', Lindbergia 17, 5-10.

Sonesson, M., Carlsson, B. A., Callaghan, T. V., Halling, S., Bjorn, L. O., Bertgren, M. and Johanson, U.: 2002, 'Growth of two peat-forming mosses in subarctic mires: species interactions and effects of simulated climate change', Oikos 99, 151-160.

Svensson, G.: 1988, 'Fossil plant communities and regeneration patterns on a raised bog in South Sweden', J. Ecol. 76, 41-59.

Tallis, J. H. and Birks, H. J. B.: 1965, 'The past and present distribution of Scheuchzeria palustris L. in Europe', J. Ecol. 53, 287-298.

Thormann, M. N. and Bayley, S. E.: 1997a, 'Aboveground net primary production along a bog-fen-marsh gradient in southern boreal Alberta, Canada', Ecoscience 4, 374-384.

Thormann, M. N. and Bayley, S. E.: 1997b, 'Aboveground plant production and nutrient content of vegetation of six peatlands in Alberta, Canada', Plant Ecol. 131, 1-16.

Thormann, M. N., Bayley, S. E. and Szumigalski, A. R.: 1998, 'Effects of hydrologic changes on aboveground production and surface water chemistry in two boreal peatlands in Alberta: Implications for global warming', Hydrobiologia 362, 171-183.

Titus, J. E. and Wagner, D. J.: 1984, 'Carbon balance for two Sphagnum mosses: water balance resolves a physiological paradox’, Ecology 65, 1765-1774.

Weltzin, J. F., Bridgham, S. D., Pastor, J., Chen, J. and Harth, C.: 2003, 'Potential effects of warming and drying on peatland plant community composition', Global Change Biol. 9, 141-151.

Weltzin, J. F., Harth, C., Bridgham, S. D., Pastor, J. and Vonderharr, M.: 2001, 'Production and microtopography of bog bryophytes: Response to warming and water-table manipulations', Oecologia 128, 557-565.

Weltzin, J. F., Pastor, J., Harth, C., Bridgham, S. D., Updegraff, K. and Chapin, C. T.: 2000, 'Response of bog and fen plant communities to warming and water-table manipulations', Ecology 81, 34643478 .

Wieder, R. K.: 2001, 'Past, present, and future peatland carbon balance: An empirical model based on ${ }^{210} \mathrm{~Pb}$-dated cores', Ecol. Appl. 11, 327-342. 